Piotr Prusinowski $\odot$ https://orcid.org/0000-0002-5805-9908

Uniwersytet Warmińsko-Mazurski w Olsztynie

\title{
LIKWIDACJA STANOWISKA PRACY A WYPOWIEDZENIE UMOWY O PRACE
}

\section{Abstract \\ Elimination of position against termination of an employment contract}

The concept of elimination of a job position does not appear in the Labour Code, however, it is commonly used in legal discussion. An attempt at clarifying its meaning encounters considerable difficulties, which is related to the fact that the term "position" is ambiguous. The relationship between the position and the type of work remains particularly disputable. The indicated issue becomes relevant when the contract of employment is terminated due to elimination of a job position. In this case, the way the elimination of a position is understood has a direct impact on the legitimacy of claims made by the employee. Employer finds itself in a favourable situation due to the perception of this term as being dominated by the organisational aspect. In many cases it is impossible to effectively terminate the employment contract by equating a job position with the contractual type of work.

Słowa kluczowe: stanowisko pracy, likwidacja, wypowiedzenie umowy o pracę, pracownik, pracodawca Keywords: position, elimination, termination of employment contract, employee, employer

ASJC: 3308, JEL: K31

\section{Wprowadzenie}

W praktyce stosowania prawa często mówi się o „likwidacji stanowiska pracy”. Za posługiwaniem się tym pojęciem nie przemawia jednak tekst Kodeksu pracy. O ile wspomina się w nim o „stanowisku pracy”, to jednak nie w kontekście jego likwidacji. Brak ten skonfrontowany z powszechnością korzystania $\mathrm{z}$ omawianego zwrotu skłania do refleksji. Po rozszerzeniu materiału badawczego, okazuje się, że „likwidacja stanowiska pracy" występuje w niektórych pozakodeksowych aktach prawnych (np. ustawa $\mathrm{z} \mathrm{dn}$. 24 sierpnia 2001 r. o restrukturyzacji hutnictwa żelaza i stali, Dz.U. 2001, nr 111, poz. 1196 ze zm.). Kierując się enumeratywnym wyliczeniem zawartym w art. 118a ust. 2 ustawy z dn. 21 listopada 1967 r. o powszechnym obowiązku obrony Rzeczypospolitej Polskiej 
(Dz.U. 2018, poz. 1459 tekst jedn.) można wnosić, że występuje gradacja przyczyn uzasadniających rozwiązanie stosunku pracy z przyczyn niezależnych od pracownika. Najdalej idące jest ogłoszenie upadłości lub likwidacja zakładu pracy (pracodawcy), następnie likwidacja stanowiska pracy, a na końcu „przyczyny niedotyczące pracownika”, o których mowa w art. 1 ust 1 ustawy z dn. 13 marca 2003 r. o szczególnych zasadach rozwiązywania z pracownikami stosunków pracy z przyczyn niedotyczących pracowników (Dz.U. 2018, poz. 1969 tekst jedn.). Problem z „,likwidacją stanowiska pracy” polega jednak na trudnościach związanych z wyjaśnieniem tego pojęcia. Nawet te nieliczne przepisy, które odwołują się do tego zwrotu, nie zawierają żadnych wskazówek interpretacyjnych. Zresztą sam termin „stanowisko pracy” nie jest jednoznaczny. W tych okolicznościach głoszenie stanowczych wniosków staje się problematyczne, a wykładnia operatywna prowadzi do tworzenia wzorców, które tylko w luźny sposób powiązane są z przekazem normatywnym.

Likwidacja stanowiska pracy jest pojęciem złożonym. Dokonując jego rozbioru, należy wskazać na aspekt czynnościowy i przedmiot mu podlegający. Aby badać, na czym polega zdarzenie zwane likwidacją, trzeba najpierw dookreślić materię podlegającą zmianie. Zależność ta wyznacza dalszą kolejność rozważań.

\section{Stanowisko pracy}

Przedmiotem zobowiązania pracownika jest „wykonywanie pracy określonego rodzaju”. $\mathrm{Na}$ tym nie kończy się jednak przekaz z art. $22 \$ 1$ k.p. Trudno bowiem pominąć, że chodzi wprawdzie o rodzajową realizację pracy, jednak w specyficznych uwarunkowaniach, to jest pod kierownictwem pracodawcy, a także w miejscu i czasie przez niego wyznaczonym. Wymienione zmienne wyznaczają zakres znaczeniowy pojęć „rodzaj pracy” $i$ „stanowisko pracy”. Pierwszy termin koncentruje uwagę na relacji kontraktowej. Zgodnie $\mathrm{z}$ art. $29 \$ 1$ pkt 1 k.p. strony są obowiązane określić rodzaj pracy. Kodeks nie precyzuje sposobu tego oznaczenia. Powściągliwość ta wydaje się zrozumiała, jeśli uwzględni się, że aspekt czynnościowy może być doprecyzowany w ramach uprawnień kierowniczych zatrudniającego. Dlatego dopuszcza się elastyczne rozwiązania. Chodzi o to, aby $z$ treści postanowienia umownego można było ogólnie wnioskować o powinnościach pracownika. Oznacza to, że rodzaj pracy może zostać wyznaczony ramowo (hasłowo). W takich wypadkach nie jest wykluczone zobowiązanie pracownika do wykonywania prac o różnorodnym charakterze, których realizację będzie stosownie do potrzeb określał pracodawca. W literaturze przedmiotu określa się taką pracę jako rotacyjną (Kubot 2004, s. 33). Trafne jest jednak spostrzeżenie, że rodzajów pracy w ramach jednej umowy o pracę nie może być zbyt dużo, gdyż mogłoby to doprowadzić do deprecjacji funkcji określenia rodzaju pracy (Stelina 2014, s. 135). Reasumując, rodzaj pracy wprawdzie stanowi warunek konieczny umowy, jednak dyspozycja art. $29 \$ 1$ pkt 1 k.p. nie zostaje zrealizowania tylko wówczas, gdy umowa nie zawiera jakiegokolwiek postanowienia lub zobowiązuje do bliżej nieokreślonych czynności (Zieliński 1986, s. 8). 
Z przeprowadzonego wywodu wynika, że zakres zobowiązania pracownika nie ma jednolitego charakteru (podlega gradacji ze względu na szczegółowość zakreślenia jego ram). Odpowiada mu natomiast powinność pracodawcy. Polega ona nie tylko na zapewnieniu wynagrodzenia, ale również na „zatrudnianiu pracownika”. Jednym z przejawów tego obowiązku jest umożliwienie rzeczywistego wykonywania pracy określonego w umowie rodzaju (Liszcz 2017, s. 257). Realizacja tego obowiązku następuje przez organizację i powierzenie stanowisk pracy. Działalność w tym zakresie nie jest objęta więzią obligacyjną, wynika z uprawnień kierowniczych pracodawcy i ma charakter jednostronny. Potwierdzenie tego zapatrywania przynosi art. 94 pkt 1 k.p. Wynikają z niego dwa założenia. Po pierwsze, to pracodawca „wyznacza” stanowisko pracy (tym samym przypisanie stanowiska do pracownika co do zasady nie jest objęte umową), a po drugie, ze stanowiskiem pracy powiązany jest zakres obowiązków (przy czym jego ukształtowanie również leży w gestii zatrudniającego). W rezultacie, trzeba uznać, że w ramach uprawnień kierowniczych pracodawca może wyznaczać pracownikowi różne stanowiska pracy pod warunkiem, że powiązany z nimi zakres obowiązków koresponduje z ustalonym w umowie rodzajem pracy (nawet jeśli konwersja ta prowadzi do zmiany dotychczasowej sytuacji pracownika - na przykład w zakresie wynagrodzenia; Szubert 1976, s. 248, wyroki SN: z 12 grudnia 2010 r., II PK 215/09, LEX nr 584742; z 2 października 2008 r., I PK 73/08, LEX nr 509025); z 26 stycznia 2012 r., III PK 47/11, OSNP 2013, nr 1-2, poz. 3).

Zaprezentowana zależność stała się fundamentem zapatrywania, zgodnie z którym pojęcie „stanowisko pracy” nie ma jednorodnego znaczenia. Po pierwsze, używa się go zamiast lub obok pojęcia „rodzaj pracy”. Przez „stanowisko pracy” rozumie się więc ogół czynności organicznie związanych z tym stanowiskiem (zestaw jego funkcji). Termin ten jest innym sposobem wyrażenia tego, co można oddać za pomocą słowa „funkcja”. Mówiąc o stanowisku pracy, ma się wtedy na uwadze wszystkie funkcje przywiązane do danego stanowiska. W tym znaczeniu omawiany zwrot występuje w sformułowaniu „pracownik zajmuje określone stanowisko”. Po drugie przyjmuje się, że „stanowisko pracy” stanowi element struktury organizacyjnej zakładu pracy (w znaczeniu przedmiotowym), jej najmniejszą jednostkę o określonym celu i zakresie działania. Najczęściej stanowiska pracy są jednoosobowe, niekiedy jednak na jednym stanowisku zatrudnia się kilka osób (np. przy pracy zmianowej, w ruchu ciągłym; wyroki SN: z 9 marca 2011 r., II PK 225/10, OSNP 2012, nr 9-10, poz. 112; z 3 września 2013 r., I PK 37/13, OSNP 2014, nr 11, poz. 157; Walas 1968, s. 130; Lewandowski 1977, s. 54). Przedstawione rozróżnienie oznacza, że w tekście normatywnym, jak i języku prawnym funkcjonuje „umowne” i „strukturalne” znaczenie stanowiska pracy. Występująca między nimi różnica może niekiedy prowadzić do nieporozumień. Aby się o tym przekonać, wystarczy prześledzić przepisy nawiązujące do tego terminu.

„Zatrudnienie na stanowisku pracy”, o którym wspomina art. $36 \$ 5$ k.p. i art. $52 \$ 1$ pkt 2 i 3 k.p., nawiązuje do wątku umownego. W przepisach tych nie chodzi przecież o strukturę zorganizowaną przez zatrudniającego. Zmienną dla skrócenia okresu wypowiedzenia, czy rozwiązania umowy o pracę jest rodzaj zakontraktowanej przez pracownika pracy, 
a nie sposób wyodrębnienia stanowiska pracy przez pracodawcę. Przeciwne zapatrywanie, wiążące przyczynowość zakończenia stosunku pracy ze skonkretyzowanym stanowiskiem, osłabiałoby sytuację prawną pracownika. Staje się to zrozumiałe, jeśli weźmie się pod uwagę, że rodzaj popełnionego przestępstwa, czy charakter utraconych uprawnień, choć uniemożliwia zatrudnienie na danym stanowisku, to jednak nie zawsze skutek ten zachodzi, gdy czynniki te odniesie się do umownego rodzaju pracy.

Interesujące wnioski płyną $\mathrm{z}$ art. 78 k.p. Przepis ten $\mathrm{w} \S 1$ wskazuje, że zmienną kształtującą wysokość wynagrodzenia jest rodzaj pracy, zaś $₫ 2$ zastrzega, że zasady przyznawania pracownikom stawek wynagrodzenia uzależniane są od określonego rodzaju pracy lub określonego stanowiska. Nieuważny obserwator mógłby dojść do przekonania, że przywołane przepisy nie korespondują ze sobą. Wrażenie to ustaje, jeśli weźmie się pod uwagę, że tylko praca określonego rodzaju jest ekwiwalentna względem wynagrodzenia. Realizacja tej ogólnej zasady polega jednak na wyznaczeniu zmiennych wpływających na wysokość wynagrodzenia. Dlatego, parametryzacja wartości pracy może odwoływać się zarówno do rodzaju pracy, jak i do stanowiska pracy. W ten sposób wysokość wynagrodzenia odzwierciedlana jest aspektem czynnościowym albo organizacyjnym. Nie ma wątpliwości, że wynagrodzenie pracowników z tym samym rodzajem pracy nie musi być jednakowe. Będzie tak wówczas, gdy w ramach zorganizowanych stanowisk dojdzie do zróżnicowania wymaganych kwalifikacji, doświadczenia, czy doniosłości czynności dla pracodawcy. Elementy te służą w procesie kształtowania stanowisk pracy.

Pewne jest, że art. $97 \$ 2$ k.p. nawiązuje do strukturalnego znaczenia stanowiska pracy. Przepis stanowi bowiem, że w świadectwie pracy należy umieścić informacje o rodzaju wykonywanej pracy, a także o zajmowanych stanowiskach. Utożsamianie w tym wypadku obu pojęć sprzeciwiałoby się regule per non est, a także zakazowi wykładni synonimicznej. Przepis ten potwierdza, że identyczny rodzaj pracy można realizować na różnych, niekoniecznie identycznych stanowiskach pracy. Na marginesie trzeba dodać, że akt wykonawczy dotyczący świadectw pracy wychodzi poza wskazany dualizm i stwierdza, że w świadectwie pracy należy zamieścić informację o rodzaju wykonywanej pracy, zajmowanych stanowiskach lub pełnionych funkcjach $(\$ 2$ pkt 3 rozporządzenia Ministra Rodziny, Pracy i Polityki Społecznej z dn. 30 grudnia 2016 r. w sprawie świadectwa pracy, Dz.U. 2018, poz. 1289 tekst jedn.). Oznacza to, że obok znanych już pojęć pojawia się jeszcze „funkcja pełniona przez pracownika”. Wydaje się, że owa funkcja, to nic innego jak stanowisko pracy albo rodzaj pracy, a tworzenie nowych i nieznanych Kodeksowi pojęć można usprawiedliwić tylko celem informacyjno-opisowym, który nie wpływa na dyrektywy wykładni tekstu prawnego.

Pozostałe przepisy Kodeksu pracy odwołują się do rodzaju pracy i stanowiska pracy albo tylko do jednego $\mathrm{z}$ tych pojęć. Analizując ich treść, można dookreślić zakres desygnatów omawianych pojęć. Do obu czynników należy przymierzać i ustalać kwalifikacje zawodowe (art. 102 k.p.). Właściwość ta pozwala sprawdzić przydatność pracownika zarówno w ramach rodzaju pracy, jak i na zorganizowanym stanowisku. $\mathrm{Z}$ przepisu tego można wnioskować, że tworzenie stanowisk pracy jest fakultatywne. 
Szczególnie u pracodawców zatrudniających niewielką liczbę pracowników oba terminy mogą mieć ten sam zakres. Będzie tak wówczas, gdy pracodawca rezygnuje z działań strukturalnych. Spostrzeżenie to potwierdza art. $104^{1} \$ 1$ pkt 7 k.p., który stanowi, że w regulaminie pracy ustala się zarówno rodzaj pracy, jak i wykaz stanowisk dozwolonych pracownikom młodocianym (art. $104^{1} \$ 1$ pkt 7 k.p.). A contrario, trzeba przyjąć, że regulamin pracy nie wymaga od pracodawcy tworzenia siatki stanowisk pracy. $Z$ tej perspektywy trudno zrozumieć, że występowanie przekroczenia najwyższych dopuszczalnych stężeń lub natężeń czynników szkodliwych dla zdrowia kojarzone jest ze stanowiskiem pracy, a nie z jej rodzajem (art. 148 pkt 1 k.p., art. $151 \$ 2$ k.p.). Jedynym wyjaśnieniem tej sytuacji jest interpretacja, zgodnie $\mathrm{z}$ którą $\mathrm{w}$ przepisach tych stanowisko pracy rozumiane jest dwojako, jako element jednostronnie wyodrębniony przez pracodawcę, a także jako synonim rodzaju pracy. Opisane wątpliwości nie występują już w art. $207^{1} \$ 1$ pkt 1 k.p. Pracodawca ma informować o zagrożeniach dla życia i zdrowia, przy czym nie ma wątpliwości, że mogą one dotyczyć zarówno zakładu pracy, poszczególnych stanowisk, jak i wykonywania danych prac. Odwrotnie natomiast prawodawca podszedł w art. $176 \$ 1$ k.p. przy okazji problemu występowania prac uciążliwych, niebezpiecznych lub szkodliwych dla zdrowia. Kryterium stanowiskowe nie ma w tym wypadku znaczenia, wystarczy, że dane czynności wykonywane są w warunkach kwalifikowanych. Do tego wątku nawiązuje art. $179 \$ 1$ i 2 k.p. Stwierdza, że w razie wystąpienia tych prac, pracodawca zobowiązany jest „przenieść pracownicę do innej pracy” lub „dostosować warunki pracy”. Przepis art. $179 \$ 4$ k.p. precyzuje, że dostosowanie warunków pracy polega na ich zmianie w ramach dotychczas zajmowanego stanowiska. W tym wypadku prawodawca zdecydował się na wyróżnienie nie tyle rodzaju pracy, co poszczególnych czynności mogących się w nim zawierać. Wskazane zagrożenie zmusza i upoważnia, stosownie do okoliczności, do jednostronnej zmiany umownego rodzaju pracy albo do działania mniej ingerującego, czyli do przemodelowania stanowiska pracy, tak aby nie zawierało ono prac uciążliwych, niebezpiecznych lub szkodliwych dla zdrowia.

W kodeksie pracy występują liczne przypadki, w których nie ma wątpliwości, że stanowisko pracy odnajduje się tylko w aspekcie organizacyjnym. Ustawodawca zakłada, że pracodawca może tworzyć jednostki organizacyjne, w strukturze których będą znajdować się stanowiska pracy (argument z art. $67^{10} \$ 1$ pkt 1 k.p.). Przepisy Kodeksu pracy podkreślają też znaczenie stanowiska pracy. Można wyróżnić relację zachodzącą między zatrudnionym a zajmowanym przez niego stanowiskiem. Polega ona na „obecności pracownika na stanowisku pracy” (art. $67^{11} \S 2$ pkt 2 k.p.), co daje podstawy sądzić, że rozpatrywany termin posiada wymiar temporalny i miejscowy. Nie ma przy tym wątpliwości, że to pracodawcy przyznano przywilej „organizowania stanowisk pracy”. Zgodnie z art. 212 pkt 1 k.p. wyznacznikiem tego urządzania są przepisy dotyczące BHP. W tym zakresie, pracodawca ma obowiązek wydawać szczegółowe instrukcje i wskazówki (art. $237^{4} \$ 2$ k.p.). Rolą pracodawcy jest również „wyposażanie stanowisk pracy” w maszyny i inne urządzenia techniczne (art. 217 k.p.). Ze stanowiskiem pracy powiązano też wymogi w zakresie zapewnienia 
pracownikowi odzieży i obuwia roboczego (art. $237^{7} \$ 2$ i 3 k.p.). Obowiązkiem pracodawcy jest także określenie środków ochrony indywidualnej, odzieży i obuwia przewidzianych dla danego stanowiska pracy (art. $237^{8} \$ 1$ k.p.), a skutkiem zakaz dopuszczania pracownika do pracy na tym stanowisku bez tych środków, odzieży i obuwia (art. $237^{9} \$ 1$ k.p.).

Pozostając w tym samym nurcie rozważań, trzeba zaznaczyć, że Kodeks pracy wyróżnia „,dotychczasowe stanowisko”, „stanowisko równorzędne”, a także „stanowisko odpowiadające kwalifikacjom zawodowym" (art. $183^{2}$ k.p.i art. $186^{4}$ k.p.). Znany jest też podział na "to samo stanowisko", „, stanowisko o takich samych warunkach pracy”, a także „inne stanowisko pracy” (art. $229 \$ 1$ pkt 2 i $\$ 1^{1}$ pkt 1 k.p. i art. $237^{3} \$ 2$ k.p.). Podziały te, choć mogą wydawać się niekoherentne, to jednak wpisują się w ten sam wzorzec. Wyznacza go zależność między powierzanym stanowiskiem pracy a umówionym rodzajem pracy. „Stanowisko równorzędne” i „stanowisko o takich samych warunkach pracy” nie wykracza poza postanowienie $\mathrm{z}$ art. $29 \$ 1$ pkt 1 k.p. Inaczej jest przy „stanowisku odpowiadającym kwalifikacjom zawodowym” oraz przy „,innym stanowisku”.

\section{Brak zapotrzebowania na pracę czy likwidacja stanowiska pracy?}

Powstaje pytanie o znaczenie terminu likwidacja stanowiska pracy. Nie jest jasne, czy chodzi w tym wypadku tylko i wyłącznie o aspekt strukturalny (organizacyjny), czy też likwidacja ma być synonimem braku zapotrzebowania na pracę danego rodzaju. W pierwszym przypadku pracodawca ma większe możliwości wykazania potrzeby rozwiązania umowy o pracę. Wystarczy, że wykaże, że zlikwidował dane stanowisko pracy, a okoliczność, że pracownik w ramach łączącej go umowy o pracę może wykonywać inne prace, będzie bez znaczenia. Druga myśl interpretacyjna nie prowadzi do tego rodzaju konstatacji. W tym znaczeniu likwidacja stanowiska pracy okaże się synonimem braku zapotrzebowania na dany rodzaj pracy.

Analiza orzecznictwa i wypowiedzi doktryny wskazują, że dominuje pierwsze spojrzenie, choć trudno pominąć, że dochodzi również do odwoływania się do drugiego znaczenia. Szczegółową prezentację należy rozpocząć od spostrzeżenia, że w ramach uprawnień kierowniczych, a także zważywszy na ponoszenie ryzyka prowadzonej działalności, pracodawca ma prawo dokonywać zmian w strukturze organizacyjnej służącej do realizacji przyświecających mu celów, a kontroli sądowej nie podlega merytoryczna trafność dokonanych zmian (np. od strony biznesowej; postanowienie SN z 2 lutego 2012 r., II PK 252/11, LEX nr 1215430). Wynika to stąd, że autonomia zarządcza pracodawcy nie została poddana ocenie sądowej (uchwała pełnego składu Izby Pracy i Ubezpieczeń Społecznych SN z 27 czerwca 1985 r., III PZP 10/85; wytyczne w przedmiocie stosowania art. 45 k.p., OSNCP 1985, nr 11 poz. 164, teza IX; wyroki SN: z 16 października 1992 r., I PRN 40/92, LEX nr 14962; z 27 listopada 1997 r., I PKN 401/97, OSNP 1998, nr 18, poz. 542). Stwierdzenia te nie świadczą jeszcze o zasadności rozwiązywania umowy o pracę z pracownikiem, którego stanowisko zostało zlikwidowane. Mimo poprawności 
tego wnioskowania, orzecznictwo sądowe uznaje, że skoro pracodawca ma prawo do modelowania struktury zakładu pracy, to dokonanie tych zmian usprawiedliwia działania zmierzające do zakończenia stosunku pracy. Zabezpieczenie praw pracownika odbywa się nie przez konfrontację z zapotrzebowaniem na wykonywanie pracy określonego rodzaju, ale przez możliwość weryfikowania prawdziwości przeprowadzanych przez zatrudniającego zmian.

Likwidacja stanowiska pracy może być zarówno wynikiem zmniejszenia liczby pracowników (wyrok SN z 23 maja 1997 r., I PKN 176/97, OSNAPiUS 1998, nr 9, poz. 263), jak i polegać na zmianie rozkładu zadań (wyrok SN z 11 lutego 2014 r., II PK 144/13, LEX nr 1483614), zmniejszeniu liczby zadań (wyroki SN: z 26 stycznia 2000 r., I PKN 487/99, OSNAPiUS 2001, nr 11, poz. 380 i z 4 grudnia 2013 r., II PK 67/13, LEX nr 1418806), w tym na rozdzieleniu zadań przypisanych do danego stanowiska na innych pracowników (wyroki SN: z 20 maja 2014 r., I PK 271/13, LEX nr 1663120 i z 3 września 2013 r., I PK 41/13, OSNP 2014, nr 8, poz. 116) albo kumulacji stanowisk (wyrok SN z 17 czerwca 2014 r., II PK 247/13, LEX nr 1496284). Przeprowadzenie tych zmian uzasadnia wypowiedzenie umowy o pracę, chyba że zostanie wykazana ich fikcyjność. Ma ona miejsce, gdy za pracownika zostanie zatrudniona inna osoba w niższym wymiarze czasu pracy (wyrok SN z 15 grudnia 1982 r., I PRN 130/82, OSNCP 1983, nr 8, poz. 121). Pozorna likwidacja stanowiska zachodzi również wówczas, gdy dochodzi tylko do zmiany jego nazwy lub nieistotnej zmiany zakresu związanych z nim zadań (wyroki SN: z 19 maja 2011 r., III PK 75/10, LEX nr 901632 i z 20 czerwca 2018 r., I PK 48/17, niepubl.). Argumentem za tym może być przyjęcie innej osoby na miejsce pracownika (Gersdorf, Żmuda 2008, s. 12).

Przedstawiony wzorzec ocenny wymaga porównywania stanowisk pracy. Twierdzi się, że likwidacja konkretnego (jedynego danego rodzaju) stanowiska pracy skutkująca zmianą struktury zakładu pracy uzasadnia zwolnienie pracownika, który był zatrudniony na tym stanowisku pracy, bez potrzeby oceny przez pracodawcę kwalifikacji, stażu pracy itp. zwalnianego i porównywania go z pracownikami zatrudnionymi na stanowiskach innego rodzaju. Potrzeba takiego porównania powstaje bowiem wówczas, gdy następuje likwidacja jednego lub kilku spośród większej liczby jednakowych stanowisk i konieczne jest dokonanie wyboru pracowników, z którymi zostanie zakończony stosunek pracy (wyroki SN: z 3 listopada 2010 r., I PK 93/10, LEX nr 707852 i z 16 listopada 2006 r., II PK 81/06, LEX nr 950625).

Poglądy orzecznicze kierujące uwagę na aspekt porównawczy nie są jednak konsekwentne. Trudno nie oprzeć się wrażeniu, że postulowanym przedmiotem konfrontacji jest nie tylko zakres czynności przypisanych do badanych stanowisk, ale również inne czynniki, które wprost wynikają z postanowień umowy o pracę. W tym duchu twierdzi się, że należy badać, czy treść stosunku pracy (warunki pracy i płacy) pracownika zatrudnionego na nowym (formalnie) stanowisku nie różni się w istotnych elementach (takich, których zmiana wymaga wypowiedzenia) od treści stosunku pracy pracownika zatrudnionego na stanowisku zlikwidowanym (formalnie; wyrok SN z 22 listopada 2001 r., I PKN 680/00, OSNAPiUS 2003, nr 20, poz. 488). Chodzi nie tylko o porównanie zakresu 
czynności (obowiązków) pracownika (wyrok SN z 16 listopada 2001 r., I PKN 688/00, OSNAPiUS 2003, nr 20, poz. 485), ale także o inne warunki pracy i płacy. W rezultacie pozorność likwidacji stanowiska pracy należy weryfikować z pozycji wielu czynników, przykładowo warunków płacowych (nieprzysługiwania niektórych składników, na przykład dodatku funkcyjnego) czy skutków zmian organizacyjnych polegających na konwersji systemu podległości pracowników. Wskazane zmienne stanowią istotny element treści umowy o pracę, co świadczy o autentyczności likwidacji stanowiska pracy (wyrok SN z 4 września 2007 r., I PK 92/07, OSNP 2008, nr 19-20, poz. 286).

Mimo akcentowania tego wątku (który ewidentnie nawiązuje do aspektu umownego, a nie organizacyjnego) w orzecznictwie przesądzono, że czynności wykonywane przez pracownika na likwidowanym stanowisku mogą być powierzane innym pracownikom (na innych stanowiskach pracy), a nawet osobom (podmiotom) niepozostającym $\mathrm{z}$ pracodawcą $\mathrm{w}$ stosunku pracy. $\mathrm{Z}$ tego powodu powierzenie tych samych obowiązków zleceniobiorcy czy też osobie prowadzącej działalność gospodarczą stanowi likwidację stanowiska pracy, uzasadniającą wypowiedzenie stosunku pracy z przyczyn dotyczących zakładu pracy. Dochodzi wówczas do likwidacji stanowiska pracy, mimo że nadal określone zadania są wykonywane na rzecz pracodawcy (wyroki SN: z 12 lipca 2001 r., I PKN 541/00, OSNAPiUS 2003, nr 11, poz. 269 i z 12 grudnia 2001 r., I PKN 733/00, OSNAPiUS 2003, $\mathrm{nr} 23$, poz. 569).

W uzupełnieniu trzeba dodać, że orzecznictwo zwróciło uwagę na inne czynniki łagodzące niekorzystną sytuację pracownika. Wskazano, że wprawdzie celowość i zasadność dokonywanych zmian nie wpływają na trafność wypowiedzenia umowy o pracę, to jednak kryteria te mogą posłużyć do przesądzenia, czy likwidacja była autentyczna, czy też pozorna (wyroki SN: z 17 września 1982 r., I PRN 64/82, OSNCP 1983, nr 4, poz. 61 i z 15 grudnia 1982 r., I PRN 130/82, OSNCP 1983, nr 8, poz. 121, OSPiKA 1983, z. 9, poz. 185; uchwała SN z 22 stycznia 1985 r., III PZP 53/84, PiZS 1985, nr 8-9, s. 86). Oznacza to, że aspekt ten nie decyduje o prawidłowości czynności pracodawcy, a jedynie służy do oceny, czy czynność ta faktycznie ma znaczenie prawne, gdyż doprowadziła do skutecznej zmiany struktury stanowisk pracy (wyrok SN z 29 kwietnia 1997 r., I PKN 119/97, OSNAPiUS 1998, nr 1, poz. 13). Dodano jednocześnie, że wskazane wyłączenie nie ma zastosowania, jeśli pracownik został przywrócony do pracy na „zlikwidowane” stanowisko pracy. Pracodawca nie ma prawa do złożenia kolejnego oświadczenia o rozwiązaniu więzi pracowniczej z powołaniem się na likwidację stanowiska pracy (wyrok SN z 4 listopada 2014 r., II PK 16/14, LEX nr 1554330). Okoliczność tę powinien podnosić w poprzednim postępowaniu w kontekście niecelowości lub niemożności przywrócenia do pracy (art. $45 \$ 2$ k.p.; wyrok SN z 9 maja 2013 r., II PK 245/12, LEX nr 1331288). W opisywanym przypadku sąd nie tyle bada zasadność zmian organizacyjnych, ile uznaje je za czynnik niewpływający na dopuszczalność przywrócenia pracownika do pracy na poprzednich warunkach.

Do tego samego nurtu należy zaliczyć postulat, zgodnie z którym w sprawach o roszczenia z tytułu rozwiązania stosunku pracy bada się nie tylko, czy likwidacja stanowiska pracy była realna, czy pozorna, ale również to, czy między nią a wypowiedzeniem 
(rozwiązaniem) stosunku pracy zachodził związek przyczynowy (wyrok SN z 5 września 2001 r., I PKN 613/00, OSNAPiUS 2003, nr 15, poz. 351). Zmiany organizacyjne muszą wprost rzutować na stanowisko zajmowane przez pracownika (wyroki SN: z 8 czerwca 2001 r., I PKN 453/00, OSNAPiUS 2003, nr 8, poz. 196 i z 13 grudnia 2005 r., II PK 103/05, LEX nr 448052). Wystąpienie tylko następstwa czasowego nie jest wystarczające (wyrok SN z 11 lipca 2017 r., I UK 291/16, LEX nr 2349418). Rozróżnienie to ma znaczenie, jeśli weźmie się pod uwagę, że zasadność wypowiedzenia umowy o pracę mierzona jest również motywacją postępowania pracodawcy. Oznacza to, że roszczenia pracownika są trafne, jeśli wprawdzie doszło do likwidacji stanowiska, jednak zatrudniający, wypowiadając umowę o pracę, kierował się innymi przyczynami - na przykład odwetem wobec pracownika, który dążył do realizacji zagwarantowanych mu praw (postanowienie SN z 9 stycznia 2014 r., I PK 182/13, LEX nr 1646043), czy też innymi zastrzeżeniami do jego pracy (postanowienie SN z 14 marca 2018 r., II PK 123/17, LEX nr 2488062), a także niemożliwością rozwiązania umowy z uwagi na przysługującą pracownikowi ochronę (wyroki SN: z 3 października 1995 r., I PRN 62/95, OSNAPiUS 1996, nr 7, poz. 101 i z 4 marca 2015 r., I PK 183/14, LEX nr 1678951). W takim przypadku pozorność nie dotyczy likwidacji stanowiska pracy, ale przyczynowości mającej uzasadniać wypowiedzenie umowy o pracę, którą deklaruje pracodawca (wyrok SN z 6 kwietnia 2007 r., II PK 265/06, LEX nr 737264).

Skupienie uwagi na aspekcie strukturalnym, a nie na umówionym rodzaju pracy zmusza do przesądzenia, czy stanowisko pracy jest „jednorodne”, czy też występuje ich w zakładzie pracy więcej. Nie są jasne kryteria tego rodzaju oceny. Poza wskazanymi już wątpliwościami pojawiają się inne problemy. Po pierwsze w literaturze przedmiotu (Paruch, Stępień 2014, s. 642-643) podniesiono, że swoboda pracodawcy w kształtowaniu stanowisk pracy może doprowadzić do przeniesienia części czynności ze stanowiska likwidowanego do innego, co sprawi, że stanowisko „dociążone” stanie się równorzędne z likwidowanym. W takim wypadku można uznać, że działania pracodawcy miały charakter pozorny. Alternatywą jest twierdzenie, że pracodawca, podejmując decyzję o wypowiedzeniu umowy o pracę, powinien rozważyć, z którym z pracowników rozwiązać tę umowę.

Postawienie na aspekt strukturalny sprawia, że niekiedy nie jest jasne, jakie spektrum przyjąć w procesie porównawczym. Stanowisko pracy umiejscowione jest bowiem w danej jednostce organizacyjnej (dziale, pionie tematycznym czy też zakładzie pracy). W orzecznictwie wypowiadano na ten temat różne poglądy. W wyroku Sądu Najwyższego z 12 listopada 2014 r. (I PK 73/14, LEX nr 1567456) uznano, że w przypadku osób zatrudnionych na stanowiskach kierowniczych wybór do zwolnienia należy przeprowadzić $\mathrm{z}$ uwzględnieniem innych osób zatrudnionych na takich stanowiskach, także w innych pionach (postanowienie SN z 13 marca 2018 r., I PK 106/17, LEX nr 2488089). Trudno nie dostrzec w tym judykacie wątku związanego $\mathrm{z}$ rodzajem wykonywanej pracy. Szeroki zakres porównawczy uzasadniony został nie tylko formalnie wyodrębnionym rodzajem stanowisk pracy, ale również tożsamością obowiązków wynikających z zawartych umów o pracę. W innym orzeczeniu (wyrok SN z 1 marca 
2017 r., II PK 382/15, LEX nr 2258042) rozpoznano przypadek likwidacji jednego ze stanowisk kierownika „strefy sprzedażowej”. Zakres obowiązków tych pracowników był identyczny, pracę wykonywali jednak w innych miejscach. Sąd Najwyższy odwołał się do poglądu, że jednakowość stanowiska pracy oceniana jest w ramach pracodawcy, a nie danej komórki organizacyjnej, a aspekt miejscowy nie przesądza o nietożsamości rodzajowej stanowisk (wyrok SN z 6 listopada 2001 r., I PKN 675/00, OSNAPiUS 2003, nr 19, poz. 461). W jeszcze innym orzeczeniu (wyrok SN z 4 października 2018 r., III PK 97/17, niepubl.), wydanym w analogicznym stanie faktycznym, Sąd Najwyższy wskazał, że o unikalności stanowiska pracy nie decyduje tylko i wyłącznie jego przypisanie w strukturze organizacyjnej do określonego regionu geograficznego, na obszarze którego pracownik ma wykonywać czynności. W rezultacie likwidacja jednego ze stanowisk danego rodzaju zmusza pracodawcę do dokonania wyboru pracownika do zwolnienia. Również w piśmiennictwie (Stępień 2014, s. 414) wskazywano, że płaszczyzną porównawczą jest grupa pracowników nieograniczająca się do danego działu czy jednostki organizacyjnej pracodawcy. Zaprezentowane poglądy nie korespondują z wcześniejszym stanowiskiem głoszonym w orzecznictwie. Przyjmowano bowiem (wyrok SN z 14 marca 2013 r., I PK 243/12, LEX nr 1448686), że ograniczenie zatrudnienia w następstwie likwidacji wszystkich stanowisk pracy określonego działu lub komórki organizacyjnej nie wymaga od pracodawcy oceny pracownika z punktu widzenia jego przydatności do wykonywania pracy na innym stanowisku. Przybliżone wypowiedzi potwierdzaja wcześniejszą konstatację. Ocena zasadności wypowiedzenia umowy o pracę z powodu likwidacji stanowiska pracy rozumianego tylko $\mathrm{w}$ ujęciu strukturalnym prowadzi do poważnych problemów interpretacyjnych.

\section{Formalizm w zakresie zmiany struktury organizacyjnej}

Zmiany w kształcie zakładu pracy, których skutkiem jest likwidacja stanowiska pracy, muszą faktycznie zaistnieć. Dopiero wówczas można rozważać zasadność wypowiedzenia umowy o pracę. Problem w tym, że decyzja pracodawcy w tym względzie może być $\mathrm{w}$ mniejszym lub większym stopniu sformalizowana. W orzecznictwie wskazano, że w przypadku gdy stanowisko pracy stanowi element struktury organizacyjnej zakładu pracy, jego rzeczywista likwidacja musi mieć pokrycie w skutecznej zmianie tej struktury (wyrok SN z 16 października 1992 r., I PRN 40/92, LEX nr 14962). Wątek ten został następnie rozbudowany. Przyjęto (wyrok SN z 20 października 1998 r., I PKN 393/98, OSNAPiUS 1999, nr 23, poz. 746), że skuteczność likwidacji stanowiska pracy nie jest uzależniona od uprzedniego wprowadzenia zmian organizacyjnych $w$ regulaminie pracy w trybie art. $104^{2} \$ 1$ k.p. (w sprawie tej jednak zgoda zakładowej organizacji związkowej na zmianę regulaminu nie była wymagana). Za tym stanowiskiem przemawia argument, zgodnie z którym procedura zmiany regulaminu wynagradzania nie ma wpływu na zasadność wypowiedzenia umowy o pracę, poza tym formalna i faktyczna likwidacja stanowiska pracy nie musi ściśle zbiegać się w czasie (wyrok SN 
z 12 grudnia 2001 r., I PKN 733/00, OSNAPiUS 2003, nr 23, poz. 569). Stanowisko to może uchodzić za dyskusyjne. W innym judykacie przyjęto bowiem, że nie dochodzi do rzeczywistej likwidacji stanowiska pracy, gdy zmiany struktury organizacyjnej nie zostały zatwierdzone przez radę nadzorczą spółdzielni (jeśli tak stanowił statut spółdzielni; wyrok SN z 23 lipca 2008 r., I PK 310/07, LEX nr 500211). Wątpliwości w tym zakresie zostały szczegółowo wyjaśnione w literaturze przedmiotu (Kurzych 2013, s. 81 i n.). Przekonuje zapatrywanie, że tryb podejmowania i wykonywania decyzji o likwidacji stanowiska pracy ma znaczenie przy ocenie zasadności wypowiedzenia umowy o pracę tylko wówczas, gdy wynika z przepisów prawa pracy. Rozwinięciem tej tezy jest spostrzeżenie, że regulamin pracy (jak również wynagradzania) nie powinien zawierać postanowień odnoszących się do procedury likwidacyjnej; jeśli jest inaczej, należy przyjąć, że tego rodzaju zapisy nie mają oparcia ustawowego, a tym samym nie mają charakteru normatywnego, czyli nie stoją na przeszkodzie podjęcia decyzji o zakończeniu zatrudnienia. Stanowisko to nie ma jednak zastosowania do statutów, które z założenia zajmują się określaniem struktury organizacyjnej. Okazuje się w tym przypadku, że pracodawca nie ma pełnej swobody w likwidowaniu stanowisk pracy, a zatem w wypowiadaniu umów o pracę (Czerniak-Swędzioł, Koczur 2011, s. 69).

Przebieg procesu decyzyjnego ma jeszcze inne znaczenie. Rację ma Andrzej Kurzych (2013, s. 82 i n.), że procedura likwidacyjna zawsze składa się z trzech etapów: przedlikwidacyjnego, decyzyjnego i wykonawczego. Stosownie do stopnia zorganizowania struktury zakładu pracy, „mobilności decyzyjnej” i potrzeb pracodawcy jej przebieg może być rozłożony w czasie. Ma to znaczenie, jeśli weźmie się pod uwagę, że działania prowadzące do zakończenia umowy o pracę mierzone są również czynnikiem temporalnym. Zestawienie tych dwóch wzorców prowadzi do wątpliwości, jeśli uwzględni się, że zasadność wypowiedzenia umowy o pracę jest oceniana według stanu z dnia wręczenia pracownikowi oświadczenia woli pracodawcy (wyrok SN z 4 października 2000 r., I PKN 531/00, OSNAPiUS 2002, nr 10, poz. 234). Orzecznictwo przyjęło, że złożenie pracownikowi wypowiedzenia z powodu likwidacji stanowiska pracy przed dniem likwidacji jest dopuszczalne (wyrok SN z 12 lipca 2001 r., I PKN 548/00, OSNAPiUS 2003, nr 11, poz. 270). Zastrzega się jednak, że w takim wypadku likwidacja stanowiska musi być pewna, a okres wypowiedzenia ma się ukończyć nie wcześniej niż z dniem likwidacji stanowiska (wyrok SN z 2 grudnia 2010 r., III PK 28/10, OSNP 2012, nr 3-4, poz. 35). Rygoryzm ten jest niekiedy łagodzony. Jako zmienną wskazuje się bowiem wymóg, zgodnie z którym decyzja o likwidacji stanowiska pracy ma być na tyle zaawansowana realizacyjnie, że nie ma wątpliwości co do jej przeprowadzenia (wyroki SN: z 22 września 1999 r., I PKN 279/99, OSNAPiUS 2001, nr 2, poz. 43; z 13 października 1999 r., I PKN 290/99, OSNAPiUS 2001, nr 4, poz. 110; z 29 marca 2001 r., I PKN 325/00, OSNP 2003, nr 1, poz. 8; z 12 grudnia 2001 r., I PKN 733/00, OSNAPiUS 2003, nr 23, poz. 569; z 12 listopada 2008 r., I PK 71/08, OSNP 2010, nr 9-10, poz. 110). W tym kontekście zrozumiałe staje się, że jeśli likwidacja stanowiska pracy (zmiana struktury organizacyjnej) jest zależna wyłącznie od pracodawcy, to może on jej dokonać w każdej chwili, nawet przez czynności faktyczne. Wówczas zaciera się różnica między zamiarem 
przeprowadzenia zmian organizacyjnych a ich rzeczywistym (w znaczeniu prawnym) przeprowadzeniem. Inaczej jest, gdy likwidacja stanowiska pracy wymaga uzgodnienia (zatwierdzenia) przez podmiot niezależny od pracodawcy. W takiej sytuacji pracodawca przejawia jedynie zamiar dokonania zmian organizacyjnych, a ich rzeczywiste przeprowadzenie w znaczeniu prawnym jest od niego niezależne (wyrok SN z 19 września 2002 r., I PKN 445/01, OSNP 2004, nr 9, poz. 153). W tym wypadku oznacza to, że likwidacja stanowiska nie stanowi rzeczywistej przyczyny wypowiedzenia umowy o pracę.

Omawiany wątek wiąże się z jeszcze jedną kwestią. Likwidacja stanowiska pracy może nastąpić jeszcze przed rozwiązaniem stosunku pracy. Powstaje pytanie, jak wówczas powinien zachować się pracodawca. $Z$ pewnością można rozważać, czy wskazana przyczyna wypowiedzenia zdezaktualizowała się, a także czy dopuszczalne jest zwolnienie pracownika z obowiązku świadczenia pracy (art. $36^{2}$ k.p.). To ostatnie rozwiązanie jest jednak nieefektywne $\mathrm{z}$ uwagi na zachowanie prawa do wynagrodzenia. $\mathrm{W}$ rezultacie wymaga jeszcze rozważenia, czy zatrudniający może zastosować art. $42 \$ 4$ k.p. W przepisie tym wskazano, że chodzi o powierzenie innej pracy, a nie pracy na innym stanowisku. Oznacza to, że nie ma potrzeby stosowania powierzenia, jeśli pracownik ma wykonywać pracę odzwierciedloną w umówionym rodzaju pracy. W sytuacji gdy zatrudniający taką pracą nie dysponuje, zasadne jest sięgnięcie po art. $42 \$ 4$ k.p., jednak pod warunkiem że uzasadniają ten krok „potrzeby pracodawcy”.

Problematyka likwidacji stanowiska pracy oddziałuje również na sferę procesową. Co do zasady, nieistnienie w strukturze zakładu pracy stanowiska pracy przemawia za uznaniem niemożliwości lub niecelowości przywrócenia do pracy (wyroki SN: z 1 października 1998 r., I PKN 357/98, OSNAPiUS 1999, nr 21, poz. 680; z 14 maja 1999 r., I PKN 57/99, OSNAPiUS 2000, nr 15, poz. 576; z 4 listopada 2010 r., II PK 111/10, OSNP 2012, nr 3-4, poz. 32). Reguła ta nie ma jednak charakteru bezwzględnego (wyrok SN z 16 kwietnia 2003 r., I PK 154/02, LEX nr 81394). Decydujące znaczenie w tym przypadku ma zawsze rozważenie interesów pracodawcy i pracownika (postanowienie SN z 15 czerwca 2007 r., II PK 37/07, LEX nr 898852). Stanowisko to jest prezentowane również w stosunku do pracowników podlegających ochronie, wymienionych w art. 45 $\$ 3$ k.p. (wyroki SN: z 8 grudnia 2016 r., II PK 262/15, LEX nr 2241389 i z 9 stycznia 2018 r., III PK 9/17, LEX nr 2440456). Zważywszy na wskazane wypowiedzi, trudno nie odnieść wrażenia, że przy tak zróżnicowanych zapatrywaniach werdykt w znacznej mierze zależy od zindywidualizowanych okoliczności sprawy.

\section{Wnioski}

Przedstawiony wywód skłania do kilku konkluzji. Możliwe, że nietrafnie skojarzono likwidację stanowiska pracy z dopuszczalnością wypowiedzenia umowy o pracę. Poza sporem pozostaje, że pracodawca ma szerokie uprawnienia w sferze organizacyjnej. Z przepisów Kodeksu pracy jednoznacznie wynika, że może, a wręcz powinien tworzyć stanowiska pracy. Zrozumiałe jest zatem, że może także swobodnie je likwidować czy 
przekształcać. Nie do obrony pozostaje kwestionowanie jednostronności realizacji tych uprawnień. Argumenty te nie dają jednak podstaw do wiązania stanowiska pracy z przyczynowością rozwiązania zatrudnienia. Aspekt organizacyjny tylko w ograniczonym zakresie wchodzi w skład więzi umownej. Wyznacznikiem w tej sferze pozostaje bowiem relacja stypulacyjna. Sprowadza się ona do zależności między wykonywaniem „pracy określonego rodzaju” a „zatrudnianiem za wynagrodzeniem”. Na tej osi należy poszukiwać kryteriów świadczących o zasadności albo niezasadności wypowiedzenia umowy o pracę. Płaszczyzna odnosząca się do struktury zakładu pracy czy też organizacji procesu świadczenia pracy ma znaczenie tylko wówczas, gdy pozostaje w związku z zachowaniem pracownika (przyczyny leżące po stronie pracownika) albo gdy uniemożliwia dalsze zatrudnianie. W tym ostatnim wypadku pracodawca uprawniony jest do zakończenia zobowiązania nie tyle w przypadku zlikwidowania stanowiska, ile z racji rezygnacji z pracy określonego rodzaju. Motyw ten wprost nawiązuje do umownych deklaracji stron. Pracownik, nawiązując więź prawną, musi bowiem liczyć się z tym, że ma pracę, dopóki pracodawca zamierza daną działalność prowadzić (albo prowadzić $\mathrm{w}$ takim, a nie innym zakresie).

Za prezentowanym zapatrywaniem, poza argumentami konstrukcyjnymi, przemawiają również inne czynniki. Wystarczy wskazać, że zgodnie z art. $45 \$ 1$ k.p. sąd pracy przywraca pracownika nie na dotychczasowe stanowisko pracy, ale na poprzednie warunki pracy i płacy. Pojęcie „warunki pracy” $z$ art. $45 \$ 1$ k.p. definiowane jest elementami wskazanymi w art. $29 \$ 1$ k.p. Zważywszy na podobieństwo sytuacji pracownika przywróconego do pracy i zatrudnionego powracającego po przerwie związanej z macierzyństwem (ojcostwem), zrozumiała staje się korelacja między rodzajem pracy a rozróżnieniem na „dotychczasowe” i „równorzędne” stanowisko pracy oraz „stanowisko odpowiadające kwalifikacjom zawodowym" z art. $183^{2}$ k.p. i art. $186^{4}$ k.p. W dwóch pierwszych przypadkach wspólne jest to, że pracownik po dłuższej nieobecności może liczyć na pracę tego samego rodzaju („dotychczasowe” lub „równorzędne” stanowisko pracy), a ostatni element różni się tym, że po urlopie macierzyńskim w pewnych okolicznościach może dojść do zmiany umownego rodzaju pracy i powierzenia stanowiska „odpowiadającego kwalifikacjom zawodowym”. Zależność tę potwierdza art. $229 \$ 1$ pkt 2 i $\$ 1^{1}$ k.p., gdy wskazuje na "to samo stanowisko”, „stanowisko o takich samych warunkach pracy” $i$,inne stanowisko pracy". W rezultacie istnieje wewnętrzna niespójność między twierdzeniem, że sama likwidacja stanowiska pracy (bez względu na możliwość realizowania rodzaju pracy na innym stanowisku) stanowi uzasadnioną przyczynę wypowiedzenia, a wskazaniem, że w razie odwołania się do sądu i wygrania procesu pracownik niekoniecznie zostanie przywrócony na dotychczasowe stanowisko. Z pozycji zasadności wypowiedzenia umowy o pracę (art. $45 \$ 1$ k.p.) czynniki te powinny być równoważne.

Poza wskazanymi racjami trzeba odnotować, że proponowane spojrzenie wykluczyłoby powstawanie wielu wcześniej przedstawionych wątpliwości (w szczególności związanych z niejednoznacznością pojęcia „stanowisko pracy”, a także z formalizmem związanym z procesem likwidacyjnym). Nie bez znaczenia jest również to, że doszłoby do wzmocnienia sytuacji prawnej pracownika. 


\section{Bibliografia}

Czerniak-Swędzioł J., Koczur S. (2011) Od likwidacji stanowiska do likwidacji jednostki jako przyczyny rozwiązania stosunku pracy - kontrowersje i watpliwości, „Studia z Zakresu Prawa Pracy i Polityki Społecznej”.

Gersdorf M., Żmuda M. (2008) Ewolucja orzecznictwa Sądu Najwyższego na temat zasadności wypowiedzenia umowy o prace, „Praca i Zabezpieczenie Społeczne”, nr 6.

Gersdorf-Giaro M. (1985) Zawarcie umowy o prace, Warszawa.

Kubot Z. (2004) Praca rotacyjna w stosunku pracy, „Praca i Zabezpieczenie Społeczne”, nr 9.

Kurzych A. (2013) Likwidacja stanowiska pracy jako przyczyna wypowiedzenia umowy o prace - ujeccie proceduralne, „Monitor Prawa Pracy”, nr 2.

Lewandowski H. (1977) Uprawnienia kierownicze w umownym stosunku pracy, Warszawa.

Liszcz T. (2017) [w:] G. Goździewicz (red.), System prawa pracy, t. 2: Indywidualne prawo pracy. Część ogólna, Warszawa.

Paruch S., Stępień R. (2014) Likwidacja stanowiska pracy jako przyczyna wypowiedzenia umowy o pracę, „Monitor Prawa Pracy”, nr 12.

Stelina J. (2014) [w:] A. Sobczyk (red.), Kodeks pracy. Komentarz, Warszawa.

Stępień R. (2014) Kryteria doboru do zwolnienia z przyczyn niedotyczących pracowników, „Monitor Prawa Pracy”, nr 8.

Szubert W. (1976) Zarys prawa pracy, Warszawa.

Walas A. (1968) Problemy wypowiedzenia zmieniajacego, „Studia Prawnicze”, nr 19.

Zieliński T. (1986) Prawo pracy. Zarys systemu, cz. 2, Warszawa.

\section{Orzecznictwo}

Postanowienie SN z 15 czerwca 2007 r., II PK 37/07, LEX nr 898852.

Postanowienie SN z 2 lutego 2012 r., II PK 252/11, LEX nr 1215430.

Postanowienie SN z 9 stycznia 2014 r., I PK 182/13, LEX nr 1646043.

Postanowienie SN z 13 marca 2018 r., I PK 106/17, LEX nr 2488089.

Postanowienie SN z 14 marca 2018 r., II PK 123/17, LEX nr 2488062.

Uchwała SN z 22 stycznia 1985 r., III PZP 53/84, PiZS 1985, nr 8-9.

Uchwała pełnego składu Izby Pracy i Ubezpieczeń Społecznych SN z 27 czerwca 1985 r., III PZP 10/85, LEX nr 12880.

Wyrok SN z 17 września 1982 r., I PRN 64/82, OSNCP 1983, nr 4, poz. 61.

Wyrok SN z 15 grudnia 1982 r., I PRN 130/82, OSNCP 1983, nr 8, poz. 121.

Wyrok SN z 16 października 1992 r., I PRN 40/92, LEX nr 14962.

Wyrok SN z 3 października 1995 r., I PRN 62/95, OSNAPiUS 1996, nr 7, poz. 101.

Wyrok SN z 29 kwietnia 1997 r., I PKN 119/97, OSNAPiUS 1998, nr 1, poz. 13.

Wyrok SN z 23 maja 1997 r., I PKN 176/97, OSNAPiUS 1998, nr 9, poz. 263.

Wyrok SN z 27 listopada 1997 r., I PKN 401/97, OSNAPiUS 1998, nr 18, poz. 542.

Wyrok SN z 1 października 1998 r., I PKN 357/98, OSNAPiUS 1999, nr 21, poz. 680.

Wyrok SN z 20 października 1998 r., I PKN 393/98, OSNAPiUS 1999, nr 23, poz. 746. 
Wyrok SN z 14 maja 1999 r., I PKN 57/99, OSNAPiUS 2000, nr 15, poz. 576. Wyrok SN z 22 września 1999 r., I PKN 279/99, OSNAPiUS 2001 nr 2, poz. 43. Wyrok SN z 13 października 1999 r., I PKN 290/99, OSNAPiUS 2001 nr 4, poz. 110. Wyrok SN z 26 stycznia 2000 r., I PKN 487/99, OSNAPiUS 2001, nr 11, poz. 380. Wyrok SN z 4 października 2000 r., I PKN 531/00, OSNAPiUS 2002, nr 10, poz. 234. Wyrok SN z 8 czerwca 2001 r., I PKN 453/00, OSNAPiUS 2003, nr 8, poz. 196. Wyrok SN z 12 lipca 2001 r., I PKN 541/00, OSNAPiUS 2003 nr 11, poz. 269. Wyrok SN z 12 lipca 2001 r., I PKN 548/00, OSNAPiUS 2003, nr 11, poz. 270. Wyrok SN z 5 września 2001 r., I PKN 613/00, OSNAPiUS 2003, nr 15, poz. 351. Wyrok SN z 6 listopada 2001 r., I PKN 675/00, OSNAPiUS 2003, nr 19, poz. 461. Wyrok SN z 16 listopada 2001 r., I PKN 688/00, OSNAPiUS 2003 nr 20, poz. 485. Wyrok SN z 22 listopada 2001 r., I PKN 680/00, OSNAPiUS 2003 nr 20, poz. 488. Wyrok SN z 12 grudnia 2001 r., I PKN 733/00, OSNAPiUS 2003 nr 23, poz. 569. Wyrok SN z12 grudnia 2001 r., I PKN 733/00, OSNAPiUS 2003 nr 23, poz. 569. Wyrok SN z 29 marca 2001 r., I PKN 325/00, OSNP 2003 nr 1, poz. 8.

Wyrok SN z 19 września 2002 r., I PKN 445/01, OSNP 2004, nr 9, poz. 153.

Wyrok SN z 16 kwietnia 2003 r., I PK 154/02, LEX nr 81394.

Wyrok SN z 13 grudnia 2005 r., II PK 103/05, LEX nr 448052.

Wyrok SN z 16 listopada 2006 r., II PK 81/06, LEX nr 950625.

Wyrok SN z 6 kwietnia 2007 r., II PK 265/06, LEX nr 737264.

Wyrok SN z 4 września 2007 r., I PK 92/07, OSNP 2008, nr 19-20, poz. 286.

Wyrok SN z 23 lipca 2008 r., I PK 310/07, LEX nr 500211.

Wyrok SN z 2 października 2008 r., I PK 73/08, LEX nr 509025.

Wyrok SN z 12 listopada 2008 r., I PK 71/08, OSNP 2010, nr 9-10, poz. 110.

Wyrok SN z 3 listopada 2010 r., I PK 93/10, LEX nr 707852.

Wyrok SN z 4 listopada 2010 r., II PK 111/10, OSNP 2012, nr 3-4, poz. 32.

Wyrok SN z 2 grudnia 2010 r., III PK 28/10, OSNP 2012, nr 3-4, poz. 35.

Wyrok SN z 12 grudnia 2010 r., II PK 215/09, LEX nr 584742.

Wyrok SN z 9 marca 2011 r., II PK 225/10, OSNP 2012, nr 9-10, poz. 112.

Wyrok SN z 19 maja 2011 r., III PK 75/10, LEX nr 901632.

Wyrok SN z 26 stycznia 2012 r., III PK 47/11, OSNP 2013, nr 1-2, poz. 3.

Wyrok SN z 14 marca 2013 r., I PK 243/12, LEX nr 1448686.

Wyrok SN z 9 maja 2013 r., II PK 245/12, LEX nr 1331288.

Wyrok SN z 3 września 2013 r., I PK 37/13, OSNP 2014, nr 11, poz. 157.

Wyrok SN z 3 września 2013 r., I PK 41/13, OSNP 2014, nr 8, poz. 116.

Wyrok SN z 4 grudnia 2013 r., II PK 67/13, LEX nr 1418806.

Wyrok SN z 11 lutego 2014 r., II PK 144/13, LEX nr 1483614.

Wyrok SN z 20 maja 2014 r., I PK 271/13, LEX nr 1663120.

Wyrok SN z 17 czerwca 2014 r., II PK 247/13, LEX nr 1496284.

Wyrok SN z 4 listopada 2014 r., II PK 16/14, LEX nr 1554330.

Wyrok SN z 12 listopada 2014 r., I PK 73/14, LEX nr 1567456.

Wyrok SN z 4 marca 2015 r., I PK 183/14, LEX nr 1678951. 
Wyrok SN z 8 grudnia 2016 r., II PK 262/15, LEX nr 2241389.

Wyrok SN z 1 marca 2017 r., II PK 382/15, LEX nr 2258042.

Wyrok SN z 11 lipca 2017 r., I UK 291/16, LEX nr 2349418.

Wyrok SN z 9 stycznia 2018 r., III PK 9/17, LEX nr 2440456.

Wyrok SN z 20 czerwca 2018 r., I PK 48/17, niepubl.

Wyrok SN z 4 października 2018 r., III PK 97/17, niepubl. 